\title{
PENGEMBANGAN APLIKASI DETEKSI KEMIRIPAN DOKUMEN PROPOSAL PENELITIAN DAN PENGABDIAN MENGGUNAKAN ALGORITMA BIWORD WINNOWING Maskur ${ }^{1}$, Deny Qutara Putra²
}

\author{
${ }^{1,2}$ Program Studi Adminsitrasi Bisnis, Jurusan Administrasi Niaga, Politeknik Negeri Malang \\ ${ }^{1}$ maskur@polinema.ac.id, 2denysqp@gmail.com
}

\begin{abstract}
Abstrak
Dokumen proposal penelitian dan pengabdian kepada masyarakat merupakan syarat yang harus dipenuhi seorang peneliti atau pengabdi untuk mendapatkan pendanaan. Sering kali proposal yang akan diajukan masih memiliki tingkat kemiripan dengan penelitian atau pengabdian yang sudah pernah dilakukan sebelumnya. Pengelola ataupun reviewer dalam menilai suatu proposal masih kesulitan untuk mengetahui apakah proposal yang diajukan itu sudah pernah dilakukan ataupun belum, sehingga pengelola dan reviewer kesulitan nilai originalitas dari proposal yang diajukan. Dibutuhkan suatu algoritma yang dapat mengetahui tingkat kemiripan suatu dokumen. Algoritma Biword Winnowing digunakan untuk mencari fingerprint dari dokumen proposal. Penelitian ini menggunakan algoritma algoritma Biword Winnowing untuk mencari nilai kemiripan proposal satu dengan lainnya, sehingga setting algoritma Biword Winnowing yang baik perlu untuk dicari guna untuk meningkatkan nilai akurasi. Hasil akurasi dengan algoritma ini dibandingkan dengan aplikasi Plagiarism Checker $X$ sebagai ukuran akurasi dari Algoritma Biword Winnowing.Hasil pengujian menunjukkan bahwa nilai window dan basis sangat mempengaruhi hasil akhir similarity. Hasil rata rata dengan menggunakan Algoritma Biword Winnowing menunjukkan untuk penelitian memiliki nilai rata rata selisih $0,634635956 \%$ sedangkan untuk pengabdian bernilai $0,586314628 \%$.
\end{abstract}

Kata kunci : Biword Winnowing, Kemiripan Dokumen, Proposal penelitian, proposal pengabdian.

\section{Pendahuluan}

Dalam pengelolaan proposal penelitian dan pengabdian kepada masyarakat, untuk menghasilkan proposal yang layak didanai, proposal yang diajukan oleh peneliti dan pengabdi harus berkualitas. Salah satu yang menjadi faktornya adalah nilai originalitas dari proposal yang diajukan. Pengelola dan reviewer yang bertugas dalam mengkaji dan menilai proposal selama ini tidak bisa mengetahui apakah proposal yang diajukan itu sudah atau pernah diajukan, sehingga pengelola dan reviewer tidak tahu nilai originalitas dari proposal yang diajukan. originalitas dari dokumen terkait dengan plagiarisme dimana menggunakan ide, penulisan, hasil milik orang lain dan mempresentasikannya sebagai karya sendiri tanpa memberitahu atau mensitasi penulis yang sebenarnya Pandey, et al (2015) ,dalam kasus ini terkait dengan proposal penelitian dan pengabdian yang diajukan, maka dari itu sangatlah penting bagi pengelola dan reviewer untuk mengetahui nilai originalitas dari proposal yang diajukan.

Untuk mengatasi masalah tersebut, perlu dilakukan deteksi kemiripan proposal. Hal ini sulit jika dilakukan secara manual, sehingga perlu adanya aplikasi untuk melakukan deteksi plagiasi dokumen penelitian dan pengabdian. Algoritma yang bisa digunakan untuk melakukan deteksi kemirian dokumen proposal adalah dengan menggunakan Biword Winnowing. Biword Winnowing merupakan algoritma pengembangan dari Winnowing.

Ada dua jenis deteksi plagiasi yaitu deteksi secarai intrinsik dan deteksi secara ekstrinsik. Algoritma Winnowing tergolong metode deteksi plagiasi secara ekstrinsik karena Algoritma ini mendeteksi bagian kalimat atau kata yang memiliki kemiripan dari dokumen yang diuji plagiasinya dengan dokumen sumber. Algoritma ini merupakan pengembangan dari metode Rabin-Karp Fingerprint. Perbedaannya adalah Algoritma Winnowing menggunakan konsep window guna untuk mengoptimalkan hasil deteksi sedangkan Rabin-Karp tidak Wibowo \& Hastuti (2016). Pada pendeteksiannya, Algoritma Winnowing harus memenuhi kebutuhan mendasar yaitu Whitespace insensitivity, Noise surpression dan Position independence Setiawan (2017). Algoritma Winnowing ini bertujuan agar dapat mengidentifikasi penjiplakan atau kemiripan dokumen, termasuk bagian-bagian kecil yang mirip dalam dokumen yang berjumlah banyak seperti yang sudah dilakukan oleh Nur Fadillah Ulfa yang membuat aplikasi deteksi kemiripan dokumen guna untuk mendeteksi plagiasi Ulfa \& Mustikasari (2016). Namun, algoritma ini juga tidak terbatas untuk deteksi plagiasi saja, seperti yang sudah implementasikan oleh Sariyunti Astutik 
yang memanfaatkan algoritma ini untuk sistem penilaian esai otomatis yang dilakukannya pada tahun 2014 lalu Astutik et al (2014).

Algoritma Winnowing berfungsi untuk membuat memproses teks yang ada dalam dokumen menjadi suatu fingerprint. Algoritma tersebut akan menghitung nilai hash dari tiap k-gram dengan menggunakan fungsi rolling hash. Kemudian, dibentuk window window dari nilai hash yang terbentuk. nilai minimum hash akan ditunjuk dari setiap window yang terbentuk. nilai hash yang ditunjuk akan digunakan sebagai fingerprint dari dokumen. Fingerprint yang sudah dibentuk akan dijadikan sebagai dasar pembanding antara file dokumen lainnya. Setiawan (2017).

Penelitian lainnya, menggunakan Algoritma Winnowing yang sudah dikembangkan, yaitu dengan menggunakan pendekatan Biword (Algoritma Biword Winnowing). Perbedaan dari algoritma yang dikembangkan oleh M.Ridho dengan Algoritma Winnowing terletak pada teknik fingerprintnya. Algoritma Winnowing menggunakan teknik fingerprint berbasiskan karakter sedangkan Algoritma Biword Winnowing menggunaka teknik fingerprint berbasis 2 kata. hal ini bertujuan untuk menjaga arti kata atau frasa dalam teks dokumen Ridho (2013).

\section{Tinjauan Pustaka}

\subsection{Algoritma Rabin-Karp}

Algoritma ini merupakan algoritma versi paling awal yang digunakan dalam pembuatan finger printing berdasarkan K-Gram. K-Gram merupakan substring dengan panjang $\mathrm{K}$ dari suatu dokumen yang sudah dihilangkan simbol dan token yang ada beserta spasinya (Preprocessing). Substring yang didapat selanjutnya akan dimasukkan ke dalam fungsi hash sehingga nilai hash yang didapat bisa digunakan untuk deteksi kemiripan (Wibowo, Sudarmadi, \& Barmawi, 2013). Proses pembandingan nilai-nilai hash satu dengan yang lainnya menggunakan persamaan Dice-Similarity (Alamsyah, 2017).

\subsection{Algoritma Winnowing}

Algoritma Winnowing berfungsi untuk memproses teks yang ada dalam dokumen menjadi suatu fingerprint. Algoritma tersebut akan menghitung nilai hash dari tiap k-gram dengan menggunakan fungsi rolling hash. Kemudian, dibentuk window-window dari nilai hash yang terbentuk. nilai minimum hash akan ditunjuk dari setiap window yang terbentuk. nilai hash yang ditunjuk akan digunakan sebagai fingerprint dari dokumen dan akan dijadikan sebagai dasar pembanding dengan fingerprint file dokumen lainnya.
Secara garis besar algortima winnowing hampir sama dengan algoritma rabin karp, hanya saja yang membedakannya adalah winnowing memiliki window sedangkan rabin karp hanya k-gram saja.

\subsection{Algortima Biword Winnowing}

Algoritma Biword Winnowing merupakan Algoritma Winnowing yang sudah dikembangkan, yaitu dengan menggunakan pendekatan Biword. Perbedaan dari algoritma yang dikembangkan oleh M.Ridho ini dengan Algoritma Winnowing terletak pada teknik fingerprintnya. Algoritma Winnowing menggunakan teknik fingerprint berbasiskan karakter sedangkan Algoritma Biword Winnowing menggunakan teknik fingerprint berbasis 2 kata. hal ini bertujuan untuk menjaga arti kata atau frasa dalam teks dokumen (Ridho, 2013).

\subsection{Metode Dokumen Fingerprinting}

Metode fingerprinting adalah metode yang menelusuri karakter satu persatu pada deret karakter. Prinsip kerja dari metode dokumen fingerprinting ini adalah dengan menggunakan teknik hashing. Teknik hashing adalah sebuah fungsi yang mengkonversi setiap string menjadi bilangan. Bilangan-bilangan tersebut menghasilkan nilai-nilai fingerprints sebagai acuan dalam perhitungan kesamaan dokumen.

\section{Metodologi}

Untuk melakukan deteksi kemiripan dokumen diperlukan metode yang tepat, sehingga perlu dibuat sebuah Metode Penelitian yang dapat menjelaskan alur penggunaan Algoritma Biword Winnowing dalam penelitian ini. sehingga tahapan yang dilakukan dalam penelitian ini adalah sebagai berikut

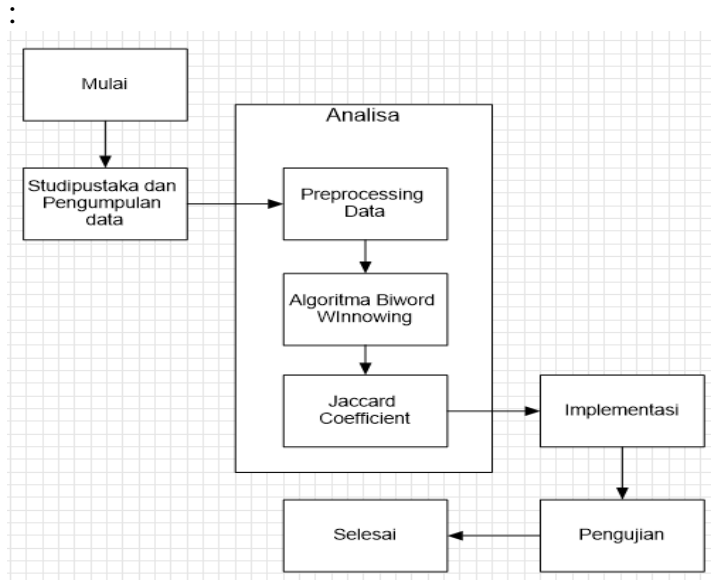

Gambar 1. Tahapan Penelitian

\section{A. Preprocessing Data}

Pembersihan teks judul dan abstrak proposal yang ada dalam Sistem Informasi Penelitian dan 
Pengabdian melalui beberapa tahap,diantaranya Siahaan et al (2017) :

1. Casefolding (Mengubah huruf kapital menjadi huruf kecil)

2. Stopping (Penghapusan kata yang tidak memiliki informasi penting)

3. Stemming (Proses merubah kata berimbuhan dalam kalimat menjadi kata dasar)

\section{B. Algoritma Biword Winnowing}

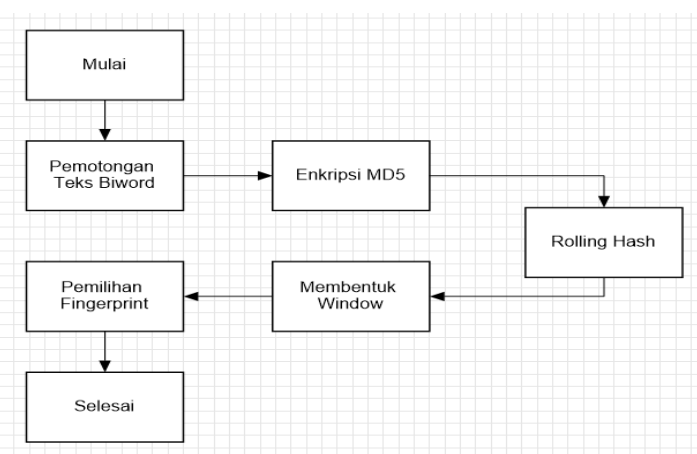

Gambar 2. Tahapan Algoritma Biword Winnowing

Pembuatan fingerprint dari judul dan abstrak proposal target dan sumber yang sudah dibersihkan. Pada tahap ini akan dilakukan :

1. Melakukan pemotongan teks yang sudah dilakukan preprocessing pada tahap sebelumnya menjadi biword yang kemudian dienkripsi menggunakan MD5

2. Menghitung nilai hash (rolling hash). rumus dari rolling hash adalah sebagai berikut :

$$
\mathrm{H}_{(1, \mathrm{n})}=\mathrm{c}_{1} * \mathrm{~b}^{(\mathrm{k}-1)}+\mathrm{c}_{2} * \mathrm{~b}^{(\mathrm{k}-2)}+\ldots \ldots .+\mathrm{c}_{\mathrm{k}} * \mathrm{~b}^{0}
$$

3. Membentuk window ukuran $\mathrm{w}$

4. Pemilihan beberapa nilai hash menjadi dokumen fingerprint.

5. Jaccard Coefficient

6. Menghitung tingkat kemiripan dokumen proposal dengan persamaan jaccard coefficient, Ridho (2013). Rumus dari Jaccard Coefficient adalah sebagai berikut :

$$
\text { Similarity }(\mathrm{di}, \mathrm{dj})=\frac{\mathrm{W}(\mathrm{di}) \cap \mathrm{W}(\mathrm{dj})}{\mathrm{W}(\mathrm{di}) \mathrm{U} \mathrm{W}(\mathrm{dj})} \times 100 \%
$$

\section{Pengujian}

Tujuan tahap pengujian ini adalah untuk mencapai nilai akurasi terbaik dari penggunaan algoritma biword winnowing. pengujian dilakukan dengan mencari nilai window (winnowing) dan nilai basis (rolling hash) terbaik untuk studi kasus deteksi dokumen proposal berdasarkan judul dan abstrak. Skenario dari pengujian yang akan dilakukan adalah sebagai berikut :

1. Mengumpulkan koleksi data judul dan abstrak proposal yang ada pada Sistem Informasi
Penelitian dan Pengabdian masing masing sebanyak 233 dengan 122 data penelitian dan 111 data pengabdian. Data yang digunakan dalam pengujian untuk mencari nilai setting terbaik adalah Data Training yang merupakan $80 \%$ dari keseluruhan data. Sisa $20 \%$ data akan digunakan sebagai Data Testing untuk menguji setting yang didapat dari hasil training. Akan dipilih dari dua kelompok masing masing satu data yang akan digunakan sebagai tolak ukur kemiripan proposal.

2. Melakukan proses deteksi kemiripan menggunakan biword winnowing dan aplikasi Plagiarism Checker $X$ sesuai dengan masing masing kelompok data. Aplikasi tersebut diperlukan sebagai pembanding guna utnuk mencari nilai margin dari window dan basis.

3. Menghitung nilai akurasi dari biword winnowing terhadap alikasi plagiarism checker dengan menggunakan nilai basis dan window yang sudah ditentukan.

\subsection{Algoritma Biword Winnowing}

Pada tahap ini akan dilakukan Pengujian algoritma biword winnowing menggunakan Matrik setting yang sudah disediakan pada tabel 2. Jika dilihat dari matrik pengujian pada tabel 2 , akan ada 64 kombinasi setting basis dan window yang akan diuji. Pengujian akan dibagi menjadi 2 tahap, yaitu tahap Training dan Tahap Testing.

\section{a. Tahap Training}

Tahap ini bertujuan untuk mengetahui nilai setting basis dan window yang terbaik yang didapat dengan mengglunakan Data Training yang sudah ditentukan sebelumnya yaitu sejumlah 240 data untuk penelitian dan 160 data untuk pengabdian. Pengujian Training melibatkan keseluruhan setting karena tahap ini akan mencari satu setting terbaik untuk masing masing kategori (penelitian dan pengabdian) dari 64 setting yang ada pada matrix tabel 2 .

Total data yang didapat dari hasil training ialah sebanyak 15.360 (64 x 240) untuk penelitian dan 10.240 (64 x 160) untuk pengabdian. selisih persentase yang didapat akan cari nilai rata ratanya berdasarkan se(22)yindow dan set basis masing masing.

Tabel 1. Hasil Evaluasi Training Detail Menggunakan Data Proposal Penelitian

\begin{tabular}{|c|c|c|c|c|}
\hline Window & Basis & $\begin{array}{c}\text { Rata Rata } \\
\text { Hasil } \\
\text { Biword } \\
\text { Winnowing } \\
(\boldsymbol{\%})\end{array}$ & $\begin{array}{c}\text { Rata } \\
\text { Rata } \\
\text { Hasil } \\
\text { Plagiaris } \\
\mathbf{m}\end{array}$ & $\begin{array}{c}\text { Rata } \\
\text { Rata } \\
\text { Selisih } \\
(\boldsymbol{\%})\end{array}$ \\
& & $\begin{array}{c}\text { Checker } \\
\mathbf{X}(\boldsymbol{\%})\end{array}$ & \\
\hline 2 & 4 & 0,49361772 & 0,279285 & 0,463892 \\
& & & 714 & 119 \\
\hline
\end{tabular}


Tabel 2. Hasil Evaluasi Training Detail Menggunakan Data Proposal Pengabdian

\begin{tabular}{|c|c|c|c|c|}
\hline Window & Basis & $\begin{array}{l}\text { Rata Rata } \\
\text { Hasil Biword } \\
\text { Winnowing } \\
(\%)\end{array}$ & $\begin{array}{l}\text { Rata Rata } \\
\text { Hasil } \\
\text { Plagiarism } \\
\text { Checker X } \\
(\%) \\
\end{array}$ & $\begin{array}{l}\text { Rata Rata } \\
\text { Selisih } \\
(\%)\end{array}$ \\
\hline \multirow[t]{2}{*}{ 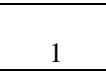 } & & 0,42578625 & & 0,4434389 \\
\hline & 2 & 5 & 0,064044944 & 1 \\
\hline \multirow[b]{2}{*}{1} & & 0,42578625 & & 0,4434389 \\
\hline & 3 & 5 & 0,064044944 & 1 \\
\hline \multirow[b]{2}{*}{1} & & 0,42578625 & & 0,4434389 \\
\hline & 4 & 5 & 0,064044944 & 1 \\
\hline \multirow[b]{2}{*}{1} & & 0,42578625 & & 0,4434389 \\
\hline & 5 & 5 & 0,064044944 & 1 \\
\hline \multirow[b]{2}{*}{1} & & 0,42578625 & & 0,4434389 \\
\hline & 6 & 5 & 0,064044944 & 1 \\
\hline & & 0,42578625 & & 0,4434389 \\
\hline & 7 & 5 & 0,064044944 & 1 \\
\hline \multirow[b]{2}{*}{1} & & 0,42578625 & & 0,4434389 \\
\hline & 8 & 5 & 0,064044944 & 1 \\
\hline
\end{tabular}

Pada tabel 1 dan 2 merupakan hasil evaluasi dari data training penelitian dan pengabdian yang sudah di ambil nilai rata rata selisih yang paling kecil. Setting yang memiliki nilai rata rata selisih yang paling kecil terdapat pada nilai 0,463892119\% dengan setting window $=2$ dan basis $=4$. sedangkan untuk pengabdian terdapat pada nilai $0,44343891 \%$ dengan setting window $=1$ dan basis $=2,3,4,5,6,7$, 8. terdapat banyak nilai setting dikarenakan basis yang memiliki window 1 kecuali basis $=1$, akan memiliki hasil selisih yang sama. Sehingga basis tidak memiliki pengaruh terhadap hasil selisih jika nilai window adalah 1 kecuali basis 1 .



Gambar 3. Diagram Evaluasi Rata-Rata Selisih \% Data Proposal Pengabdian (Window x Basis)

Grafik Evaluasi Rata-Rata Selisih \% (Basis x Window)

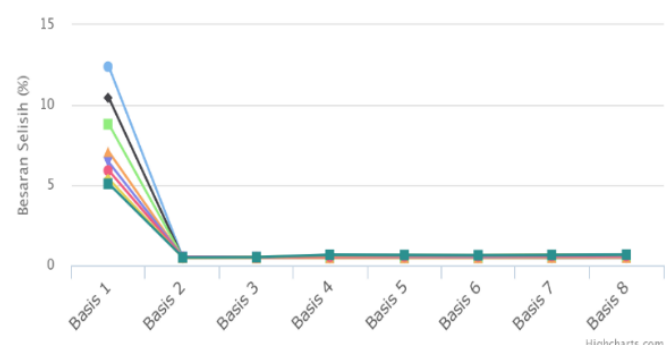

Gambar 4. Diagram Evaluasi Rata-Rata Selisih \% Data Proposal Pengabdian (Basis x Window)

Sesuai dengan Gambar 3 dan 4, nilai dari basis dan window dapat mempengaruhi hasil persentase kemiripan dokumen, hasil rata rata selisih akurasi dari basis 1 memiliki nilai selisih yang lebih besar dari basis 2 sampai 8 sehingga nilai basis 1 tidak cocok digunakan sebagai setting basis daripada basis yang lainnya.

\section{b. Tahap Testing}

Tahap ini bertujuan untuk menguji setting yang sudah didapatkan melalui tahap training dengan menggunakan data testing sehingga diharapkan hasil dari testing tidak memiliki perbedaan yang jauh dari hasil training.

Tabel 3. Setting Terbaik hasil Training Data Penelitian dan Pengabdian

\begin{tabular}{|l|l|l|l|l|}
\hline Kategori & Window & Basis & $\begin{array}{l}\text { Hasil } \\
\text { Selisih }\end{array}$ & Keterangan \\
\hline Penelitian & 2 & 4 & 0,463 & - \\
89211 & \\
& & & 9 & \\
\hline Pengabdian & 1 & 2 & 0,44 & $\begin{array}{l}\text { dipilih } \\
\text { basis 2 } \\
\text { untuk } \\
\end{array}$ \\
& & & 343 \\
& & & $\begin{array}{l}\text { memini } \\
\text { malisir } \\
\text { proses } \\
\text { perhitun } \\
\text { gan }\end{array}$ \\
\hline
\end{tabular}

Pada tahap training sudah didapatkan setting yang terbaik menurut hasil training. Proses yang dilakukan untuk tahap ini sama dengan tahap Training, hanya saja jumlah data yang digunakan adalah 20\% dari data keseluruhan dan hanya menggunakan 1 setting saja pada tiap kategori.

Tabel 4. Hasil Evaluasi Testing Penelitian dan Pengabdian dengan 2 Algoritma

\begin{tabular}{|c|c|c|c|c|c|c|c|}
\hline $\begin{array}{l}\mathbf{N} \\
\mathbf{0}\end{array}$ & Kategori & $\begin{array}{l}\text { Algorit } \\
\text { ma }\end{array}$ & $\mathbf{W}$ & B & $\begin{array}{l}\text { Rata } \\
\text { Rata } \\
\text { Hasil } \\
\text { Biwor } \\
\text { d } \\
\text { Winno } \\
\text { wing } \\
(\%) \\
\end{array}$ & $\begin{array}{l}\text { Rata } \\
\text { Rata } \\
\text { Hasil } \\
\text { Plagia } \\
\text { rism } \\
\text { Check } \\
\text { er X } \\
(\%) \\
\end{array}$ & $\begin{array}{l}\text { Rata } \\
\text { Rata } \\
\text { Selis } \\
\text { ih } \\
(\%)\end{array}$ \\
\hline 1 & Penelitian & $\begin{array}{l}\text { Biword } \\
\text { Winno } \\
\text { wing }\end{array}$ & 2 & 4 & $\begin{array}{r}4,7736 \\
65854 \\
\end{array}$ & $\begin{array}{r}4,2579 \\
16667 \\
\end{array}$ & $\begin{array}{r}0,63 \\
4635 \\
956 \\
\end{array}$ \\
\hline 2 & Pengabdian & $\begin{array}{l}\text { Biword } \\
\text { Winno } \\
\text { wing }\end{array}$ & 1 & 2 & $\begin{array}{r}5,1427 \\
01624 \\
\end{array}$ & $\begin{array}{r}4,7827 \\
27273 \\
\end{array}$ & $\begin{array}{r}0,58 \\
6314 \\
628 \\
\end{array}$ \\
\hline 3 & Penelitian & $\begin{array}{l}\text { Winno } \\
\text { wing }\end{array}$ & 2 & 4 & $\begin{array}{r}5,0428 \\
89450 \\
\end{array}$ & $\begin{array}{r}4,2579 \\
16667 \\
\end{array}$ & $\begin{array}{r}0,78 \\
4972 \\
784 \\
\end{array}$ \\
\hline 4 & Pengabdian & $\begin{array}{l}\text { Winno } \\
\text { wing }\end{array}$ & 1 & 2 & $\begin{array}{r}7,1876 \\
6646 \\
\end{array}$ & $\begin{array}{r}4,7827 \\
27273 \\
\end{array}$ & $\begin{array}{r}2,40 \\
4939 \\
188 \\
\end{array}$ \\
\hline
\end{tabular}

Algoritma Biword Winnowing dapat menghasilkan selisih rata-rata yang lebih kecil daripada menggnakan algortima winnowing dengan kondisi Setting W (Window) dan B (Basis) yang sama. 
Hasil rata rata selisih dengan menggunakan Algoritma Biword Winnowing menunjukkan untuk penelitian memiliki nilai rata rata selisih $0,634635956 \%$ sedangkan untuk pengabdian bernilai $0,586314628 \%$. jika dibandingkan dengan hasil dari training adalah sebagai berikut :

Tabel 5. Hasil Evaluasi Perbandingan Testing dan

Training Penelitian dan Pengabdian dengan

Menggunakan Algoritma Biword Winnowing

\begin{tabular}{|l|c|c|c|}
\hline \multirow{2}{*}{ Kategori } & \multicolumn{2}{|c|}{ Rata Rata Selisih $(\%)$} & \multirow{2}{*}{ Selisih } \\
\cline { 2 - 3 } & Training & Testing & \\
\hline Penelitian & $\mathbf{0 , 4 6 3 8 9 2 1 1 9}$ & $\mathbf{0 , 6 3 4 6 3 5 9 5 6}$ & $\mathbf{0 , 1 7 0 7 4 3 8 4}$ \\
\hline Pengabdian & $\mathbf{0 , 4 4 3 4 3 8 9 1}$ & $\mathbf{0 , 5 8 6 3 1 4 6 2 8}$ & $\mathbf{0 , 1 4 2 8 7 5 7 2}$ \\
\hline
\end{tabular}

Dari nilai selisih dapat disimpulkan bahwa untuk setting basis $=4$ dan window $=2$ pada kategori penelitian memilliki akurasi error sebesar $0,17 \%$ sedangkan untuk kategori pengabdian dengan menggunakan setting window 1 dan basis 2 memiliki akurasi error sebesar $0,14 \%$. semakin kecil nilai akurasi error maka semakin baik.

\subsection{Pengujian Plagiarism Checker $X$}

Aplikasi ini akan digunakan sebagai tolak ukur dalam melakukan pengujian algoritma biword winnowing yang sudah diimplementasikan. maka dari itu diperlukan hasil prosentase similiarity dari seluruh data. Data yang digunakan sebagai sumber dalam aplikasi ini harus sama dengan data sumber yang digunakan pada algoritma biword winnowing.



Gambar 5. Hasil Plagiarism Checker X menggunakan data Proposal Penelitian

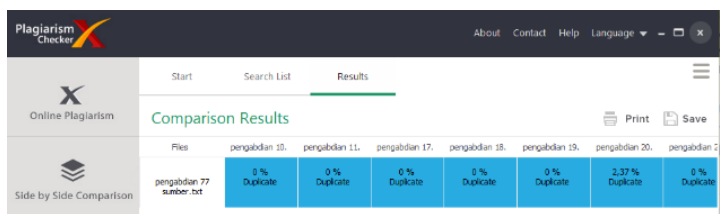

Gambar 6. Hasil Plagiarism Checker X menggunakan data Proposal Pengabdian

Pada gambar 5 dan 6 sudah ditampilkan hasil dari nilai kemiripan yang dilakukan dengan menggunakan aplikasi Plagiarism Checker X. dengan sumber proposal yang sudah ditentukan.

\subsection{Pengujian plagiasi dengan Aplikasi}

Hasil Setting terbaik yang sudah ditemukan pada tahap sebelumnya akan gunakan Algoritma Biword Winnowing untuk diimplementasikan ke dalam Sistem. Setting tersebut dapat dilihat pada tabel 5. Untuk hasil pengimplementasian deteksi kemiripan ke dalam sistem adalah sebagai berikut :

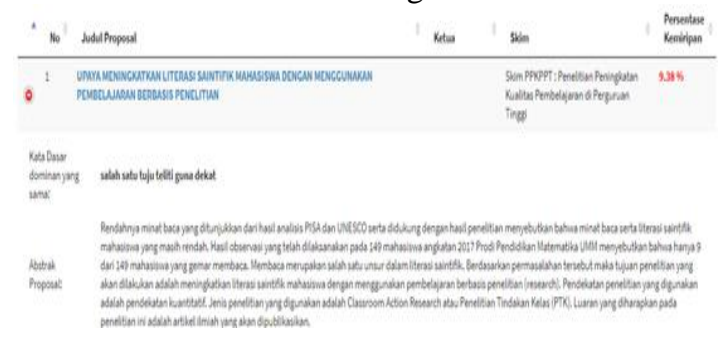

Gambar 7. Hasil Pengujian Plagiasi dengan aplikasi menggunakan algoritma biword winnowing

\section{Pembahasan}

Algoritma Biword Winnowing akan diterapkan terhadap data penelitian dan data pengabdian. Jumlah data yang digunakan untuk Training adalah $80 \%$ dari total data pada masing masing kelompok data (penelitian dan pengabdian). sedangkan sisanya yaitu $20 \%$, akan digunakan sebagain data Testing. Hasil dari algoritma ini berupa fingerprint dari masing masing data yang nantinya akan digunakan untuk mencari nilai kemiripan.

Tabel 6. Detail Penggunaan DataSet

\begin{tabular}{|l|l|l|}
\hline Jenis Data & Penelitian & Pengabdian \\
\hline $\begin{array}{l}\text { Keseluruhan } \\
(100 \%)\end{array}$ & 300 & 200 \\
\hline $\begin{array}{l}\text { Training } \\
(80 \%)\end{array}$ & 240 & 160 \\
\hline Testing (20\%) & 60 & 40 \\
\hline
\end{tabular}

Namun nilai fingerpint yang didapat akan berbeda jika setting nilai basis (b) dan window (w) berbeda. untuk itu diperlukan training untuk menentukan nilai basis dan window yang sesuai.

Tabel 7. Nilai basis dan setting yang digunakan dalam pengujian

\begin{tabular}{|l|l|l|l|l|l|l|l|l|}
\hline $\begin{array}{l}\text { Basis } \\
\text { Window }\end{array}$ & 1 & 2 & 3 & 4 & 5 & 6 & 7 & 8 \\
\hline 1 & 1,1 & 1,2 & 1,3 & 1,4 & 1,5 & 1,6 & 1,7 & 1,8 \\
\hline 2 & 2,1 & 2,2 & 2,3 & 2,4 & 2,5 & 2,6 & 2.7 & 2,8 \\
\hline 3 & 3,1 & 3,2 & 3,3 & 3,4 & 3,5 & 3,6 & 3,7 & 3,8 \\
\hline 4 & 4,1 & 4,2 & 4,3 & 4,4 & 4,5 & 4,6 & 4,7 & 4,8 \\
\hline 5 & 5,1 & 5,2 & 5,3 & 5,4 & 5,5 & 5,6 & 5,7 & 5,8 \\
\hline 6 & 6,1 & 6,2 & 6,3 & 6,4 & 6,5 & 6,6 & 6,7 & 6,8 \\
\hline 7 & 7,1 & 7,2 & 7,3 & 7,4 & 7,5 & 7,6 & 7,7 & 7,8 \\
\hline 8 & 8,1 & 8,2 & 8,3 & 8,4 & 8,5 & 8,6 & 8,7 & 8,8 \\
\hline
\end{tabular}

Aplikasi ini akan digunakan sebagai tolok ukur dalam melakukan pengujian algoritma biword winnowing yang sudah diimplementasikan. maka 
dari itu diperlukan hasil prosentase similiarity dari seluruh data. Data yang digunakan sebagai sumber dalam aplikasi ini harus sama dengan data sumber yang digunakan pada algoritma biword winnowing.

\section{Kesimpulan dan Saran}

Berdasarkan implementasi yang sudah dilakukan sebelumnya, dapat disimpulkan bahwa :

1. Algoritma Biword Winnowing memiliki setting nilai basis pada rolling hash dan nilai window yang dapat diubah. perubahan dari dua nilai tersebut dapat mempengaruhi nilai akhir similarity yang akan dihasilkan.

2. Hasil Pengujian menunjukkan bahwa nilai basis dan window yang terbaik untuk proses similarity adalah :

a. basis $=4$ dan window $=2$ untuk data Penelitian

b. basis $=2$ dan window $=1$ untuk data Pengabdian.

3. Hasil rata rata dengan menggunakan Algoritma Biword Winnowing menunjukkan untuk penelitian memiliki nilai rata rata selisih $0,634635956 \%$ sedangkan untuk pengabdian bernilai $0,586314628 \%$.

Disamping itu Penelitian ini masih memiliki kekurangan. sehingga diharapkan penelitian selanjutnya dapat menyempurnakan dari penelitian ini, diantaranya :

1. Perlu dilakukan pengujian lebih lanjut untuk nilai basis dan window diatas 8 . hal ini perlu dilakukan untuk mengetahui pola yang jelas karena pada basis dan window dengan jarak nilai pengujian 1-8 masih tidak ditemukan pola yang jelas.

2. Perlu penanganan untuk data selain yang berbahasa Indonesia, hal ini dikarenakan pada Sistem Informasi Penelitian dan Pengabdian terdapat proposal yang menggunakan bahasa inggris.

\section{Daftar Pustaka}

Alamsyah, N. (2017) : Perbandingan Algoritma Winnowing Dengan Algoritma Rabin Karp Untuk Mendeteksi Plagiarisme Pada Kemiripan Teks Judul Skripsi. Vol 8, No.3, pp. 124-134

A. P. Utama Siahaan, Mesran, R. Rahim, D. Siregar. K-Gram as A Determinant of Plagiarism Level in Rabin-Karp Algorithm. International Journal of Scientific and Technology Reserach. 2017. Vol. 6, Issue 07.

Astutik S, Cahyani AD, Sophan MK.( 2014) : Sistem Penilaian Esai Otomatis Pada E-Learning Dengan Algoritma Winnowing. J Inform [Internet].;12(2):47-52.

Jarwati, Cahya Prihandoko A, Eka Yulia R W. ( 2016) : Penerapan Algoritma Winnowing pada Sistem Rekomendasi Penetuan Dosen
Pembimbing Skripsi (Studi Kasus: Prodi Sistem Informasi Universitas Jember Jember),;(1):1120.

Ulfa NF, Mustikasari M. (2016) : Pembuatan Aplikasi Pengukuran Tingkat Kemiripan Dokumen Berbasis Web Menggunakan Algoritma Winnowing. J Inform dan Komput. 21(3):61-8.

Oktapriansyah Lubis F, Zul MI, Rachmawati H.( 2016) : Rancang Bangun Aplikasi Pendeteksi Kemiripan File Berbasis Web Menggunakan Jaccard Coefficient dan Algoritma Winnowing. J Aksara Komput Terap Politek Caltex Riau;5(1):260-7.

Pandey A, Kaur M, Goyal P. ( 2015) : The Menace of Egalitarianism. Int Symp Emerg Trends Technol Libr Inf Serv.;(1):1-6.

Putera Utama Siahaan A, Mesran, Rahim R, Siregar D. (2017) : K-Gram As A Determinant Of Plagiarism Level In Rabin-Karp Algorithm. Int J Sci Technol Res;6(7):350-3.

Ridho M. (2013) : Rancang Bangun Aplikasi Pendeteksi Penjiplakan Dokumen Menggunakan Algoritma Biword Winnowing. Teknik Informatika Universitas Islam Negeri SLTAN Syarif Kasim Pekan Baru Riau. niversitas Islam Negeri SLTAN Syarif Kasim Pekan Baru Riau.

Rathore FA, Farooq F. (2018) : Plagiarism detection softwares: Useful tools for me dical writers and editors. Learn Res [Internet].;64(11):1329-31. Tersedia pada: http://www.jpma.org.pk/PdfDownload/7088. pdf

Setiawan A. (2017) : Implementasi Algoritma Winnowing Untuk Deteksi Kemiripan Judul Skripsi Studi Kasus STIMK Budidarma. Maj Ilm INTI;7(1):1-9.

Wibowo RK, Hastuti K. (2016) : Penerapan Algoritma Winnowing Untuk Mendeteksi Kemiripan Teks pada Tugas Akhir Manusia. TechnoCOM;15(4):303-11. 